\title{
STUDI KOMUNITAS RUMPUT LAUT PADA BERBAGAI SUBSTRAT DI PERAIRAN PANTAI PERMISAN KABUPATEN CILACAP
}

\author{
ETI FERAWATI, DWI SUNU WidyARTINI, ILALQISNy INSAN
}

Fakultas Biologi, Universitas Jenderal Soedirman, Jalan dr. Suparno 63 Purwokerto 53122

\section{A B S T R A C T}

Seaweed naturally grows in substrate of sand, mixing between sand, mud and shell fragments, and also coral. Previous researches stated that there were types of seaweed that able to grow in more than one substrates. The aims of this research was to know the community structure such as diversity, domination, evenness, and similarity of seaweed on various substrates in Permisan beach, Central java. This research used survey method and samples were randomly selected for each substrate with quadrate of $1 \times 1 \mathrm{~m}^{2}$. The research found that 20 kinds of seaweeds with biomass for about 4,669 g. Seven kinds of seaweed that grow in sand substrate with biomass for about $0,636 \mathrm{~g}, 20$ kinds of seaweed in coral substrate with biomass for about 2,399 g, and 12 kinds of seaweeds in mixing substrate with biomass for about 1,634 g. Diversity index value in Permisan beach was ranging between 0,064-0,828 and categorized as low. Domination index value was ranging between 0,213-1,193, which means there was dominating variety. Evenness index value was ranging between $0,021-0,276$, which means the community was unstable. The highest similarity index value was coral substrate-mixing for about $75 \%$.

KEY WoRDS: Seaweed, Community, Based Substrate, Permisan Beach, Cilacap

Penulis korespondensi: ETI FERAWATI | email: nouna_fera@yahoo.co.id

\section{P E N D A H U L U A N}

Rumput laut merupakan tumbuhan tingkat rendah yang perawakannya (habitusnya) relatif sulit dibedakan antara akar, batang dan daunnya. Keseluruhan bagian tubuhnya disebut dengan talus. Rumput laut dibedakan dalam 3 divisi utama berdasarkan atas kandungan pigmen yang dominan pada rumput laut tersebut yaitu Rhodophyta (alga merah), Phaeophyta (alga coklat), dan Chlorophyta (alga hijau) (Indrawati et al., 2007).

Ada dua tipe substrat utama yang digunakan sebagai tempat hidup rumput laut yaitu substrat lunak yang meliputi lumpur, pasir atau campuran pasir dan lumpur, dan substrat keras yang meliputi karang mati, karang hidup dan batuan. Pada perairan substrat lunak banyak dihuni oleh jenis dari Halimeda, Caulerpha, Gracilaria, dan Hypnea sedangkan pada perairan bersubstrat keras banyak dihuni oleh jenis dari Enteromorpha, Ulva, Sargassum dan Turbinaria (Kadi dan Atmadja, 1988).

Studi komunitas dapat dilakukan secara fungsional dan struktural. Secara fungsional, dapat diketahui dengan melihat fungsi dan kedudukan suatu organisme dalam rantai makanan dan piramida makanan. Secara struktural, komunitas dapat ditentukan oleh keanekaragaman jenis, kelimpahan, distribusi dan dominansi (Odum, 1971). Struktur komunitas merupakan suatu sistem dari kumpulan populasi yang hidup pada daerah tertentu dan terorganisasi secara luas dengan karakteristik tertentu, serta berfungsi sebagai kesatuan transformasi metabolis (Odum,1971).

Faktor-faktor yang mempengaruhi komunitas rumput laut dibedakan menjadi tiga, yaitu faktor oseanografi, topografis dan hayati. Kondisi oseanografis di suatu perairan (temperatur, intensitas cahaya, kedalaman, salinitas, $\mathrm{pH}$, arus dan gelombang), faktor topografis (Kondisi substrat dasar perairan), dan faktor hayati seperti hewan herbivor, serta kompetisi antara jenis rumput laut itu sendiri mempengaruhi struktur komunitas rumput laut (Lobban dan Harrison, 1994).

Pantai Permisan terdapat di Pulau Nusakambangan tepatnya sebelah selatan LP Permisan Kabupaten Cilacap, Jawa Tengah. Pantai ini masih sangat alami belum banyak tercemari oleh manusia. Substrat dasar pantainya yang bermacammacam sangat berpotensi untuk digali kekayaan rumput lautnya. Kawasan tersebut diduga memiliki keanekaragaman jenis cukup besar. Berdasarkan hal tersebut di atas maka permasalahan yang didapat dirumuskan adalah; berapakah jumlah jenis rumput laut dan biomassa yang terdapat pada berbagai substrat di perairan pantai permisan, dan bagaimanakah perbedaan jenis pada masing-masing substrat berdasarkan indeks keanekaragaman, dominansi, kemerataan dan kesamaannya.

Berdasarkan permasalahan tersebut, penelitian ini bertujuan untuk mengetahui :

1. Mengetahui jenis-jenis rumput laut dan biomassanya yang terdapat pada berbagai substrat di perairan pantai permisan.

2. Mengetahui perbedaan jenis pada masing-masing substrat berdasarkan indeks keanekaragaman, dominansi, kemerataan dan kesamaan.

Penelitian ini diharapkan dapat memberikan informasi dasar mengenai komunitas rumput laut pada berbagai substrat di pantai Permisan, Jawa Tengah secara berkelanjutan sehingga dapat dipergunakan sebagai salah satu pertimbangan dalam pengelolaan pantai Permisan secara lestari dan berkelanjutan 


\section{E T O D E}

Bahan yang digunakan dalam penelitian meliputi jenis rumput laut yang terdapat pada substrat pasir, karang dan campuran yang berada di pantai Permisan Cilacap. Alat yang digunakan dalam penelitian ini adalah tali rafia, terpal, bambu berbentuk bujur sangkar dengan ukuran $1 \times 1 \mathrm{~m}$, kantong plastik besar dan kecil, termometer, hand refractometer, $\mathrm{pH}$ meter, timbangan digital, kamera digital, meteran, label, penggaris, spidol permanen, ember, pipet tetes, botol gelap, tissue, jerigen plastik 4 liter dan gunting. Penelitian ini dilakukan di pantai Permisan, kabupaten Cilacap, Jawa Tengah. Penelitian ini dilakukan pada bulan Mei 2012. Identifikasi rumput laut akan dilaksanakan di Laboratorium Biologi Akuatik Fakultas Biologi Unsoed.

Metode yang digunakan dalam penelitian adalah metode survei dengan teknik pengambilan sampel menggunakan metode kuadrat $1 \times 1 \mathrm{~m}^{2}$, pada berbagai substrat diambil 20 plot secara acak terpilih. Parameter utama yang diamati adalah keanekaragaman, dominansi, kemerataan dan kesamaan rumput laut pada berbagai substrat. Sedangkan parameter pendukungnya adalah pengukuran faktor fisik yaitu temperatur, kedalaman, salinitas dan kecepatan ombak dan pengukuran faktor kimiawi yaitu $\mathrm{pH}$.

Plot dibuat dari bambu yang telah dipotong dengan ukuran $1 \mathrm{x} 1 \mathrm{~m}^{2}$, pengambilan sampel rumput laut dilakukan secara acak terpilih pada berbagai subtrat, yaitu pada subtrat karang, subtrat pasir, dan subtrat campuran. Setiap subtrat dilakukan 20 kali ulangan. Pengambilan sampel rumput laut dilakukan pada saat air surut. Semua jenis rumput laut yang sudah diambil dan dimasukkan ke dalam plastik yang sudah diberi label, kemudian dipisahkan menurut jenisnya. Setelah itu ditimbang berat basahnya dan difoto untuk dokumentasi.

Jenis tersebut diidentifikasi dengan menggunakan buku identifikasi Trono (1997), Atmadja (1996), Anggadireja et al (2006). Data yang diperoleh kemudian dianalisis menggunakan indeks keanekaragaman Shannon-Wienner untuk mengetahui keragamannya, indeks dominansi Simpson untuk mengetahui dominansinya, indeks kemerataan Pielou untuk mengetahui kemerataannya dan indeks kesamaan Sorensen untuk mengetahui kesaamaan jenisnya (Odum, 1971).

Pengukuran temperatur air laut, menurut Alaerts dan Santika (1987) dilakukan dengan mencelupkan termometer Celcius ke dalam perairan yang akan diamati selama 10 menit, pengukuran temperatur perairan diulang sebanyak tiga kali pada substrat pasir, karang dan campuran. Pengukuran kedalaman dilakukan pada saat air laut surut, dengan cara menggunakan penggaris yang dicelupkan kedalam perariran pada substrat pasir, karang dan campuran. Pengukuran salinitas menggunakan hand refractometer, pengukuran salinitas diulang sebanyak 3 kali, yaitu pada substrat pasir, karang dan campuran. Pengukuran $\mathrm{pH}$ menggunakan kertas $\mathrm{pH}$ yang dicelupkan ke dalam air laut sampai diperoleh perubahan warna, warna yang terlihat dicocokan dengan skala warna yang ada dan dicatat hasilnya. Pengukuran $\mathrm{pH}$ diulang sebanyak 3 kali, yaitu pada substrat pasir, karang dan campuran. Pengukuran kecepatan ombak dilakukan dengan menggunakan botol plastik yang diisi air sepertiga dari botol tersebut kemudian diikatkan dengan tali. Botol yang bertali direnggangkan sejauh $2 \mathrm{~m}$ dari garis pantai. Dihitung berapa detik botol terhempas menuju garis pantai dengan jarak 2 m tersebut, diulang sebanyak 5 kali dan hasilnya dirata-rata.

Rumput laut yang sudah diawetkan kemudian diidentifikasi dengan mencocokkan dengan gambar atau spesimen yang ada untuk menentukan jenisnya. Data jumlah jenis yang diperoleh dari pengambilan sampel rumput laut digunakan untuk menghitung keanekaragaman, dominansi, kemerataan dan kesamaan.

Untuk mengetahui keanekaragaman jenis rumput laut menggunakan rumus indeks keanekaragaman ShannonWiever (Fachrul, 2007).

$$
H^{\prime}=-\sum_{i=n}^{s}\left(\frac{n i}{N}\right) \log \left(\frac{n i}{N}\right)
$$

Keterangan:

$\mathrm{H}^{\prime} \quad$ = Indeks keanekaragaman Shannon-Wienner

ni $\quad=$ Jumlah individu dari suatu jenis $\mathrm{i}$

$\mathrm{N}=$ Jumlah total individu seluruh jenis

$\mathrm{H}^{\prime}<1=$ Menunjukkan bahwa keanekaragaman spesies pada suatu transek adalah sedikit atau rendah.

$1 \leq \mathrm{H}^{\prime} \leq 3$ = Menunjukkan bahwa keanekaragaman spesies pada suatu transek adalah sedang melimpah.

$\mathrm{H}^{\prime}>3$ = Menunjukkan bahwa keanekaragaman spesies pada suatu transek adalah melimpah tinggi.

Untuk mengtahui dominansi pada masing-masing lokasi menggunakan rumus indeks dominansi Simpson (Fachrul, 2007).

$$
D=\sum\left(\frac{n i}{N}\right)^{2}
$$

Keterangan :

$\mathrm{D}=$ Indeks dominansi

ni $=$ Jumlah biomassa tiap jenis

$\mathrm{N}=$ Jumlah total nilai biomassa

Indeks dominansi-Simpson ini bernilai antara $0-1$ dengan deskripsi sebagai berikut:

$\mathrm{D}=0$ berarti tidak terdapat jenis yang mendominasi jenis lainya atau komunitas berada dalam kondisi stabil

$\mathrm{D}=1$ berarti terdapat jenis yang mendominasi jenis lainya atau komunitas berada dalam kondisi labil karena terjadi tekanan ekologis.

Untuk mengtahui kemerataan yang digunakan adalah indeks Eveness Pielou (E) (Fachrul, 2007).

$$
E=\frac{H^{\prime}}{\ln S}
$$

Keterangan:

$\mathrm{E}=$ Indeks evenness Pielou

$\mathrm{H}^{\prime}=$ Indeks keanekaragaman

$\mathrm{S}=$ Jumlah jenis

Indeks kemerataan yang diperoleh kemudian dimasukkan dalam kriteria sebagai berikut:

$\mathrm{E}=0$, kemerataan antar jenis atau kekayaan individu masingmasing spesies berbeda.

$\mathrm{E}=1$, kemerataan antara jenis relatif rata atau jumlah individu masing - masing relatif sama.

Untuk mengetahui kesamaan jenis pada masing-masing komunitas menggunakan rumus indeks Kesamaan (Tjitrosoedirdjo et al., 1984).

$$
C=\frac{2 W}{a+b} \times 100 \%
$$

Keterangan:

$$
\begin{aligned}
& \mathrm{W} \quad=\text { banyaknya jenis yang sama terdapat pada kedua } \\
& \text { komunitas yang dibandingkan. } \\
& \begin{array}{ll}
\mathrm{A} & =\text { Jumlah jenis dalam komunitas } \mathrm{A} \\
\mathrm{B} & =\text { Jumlah jenis dalam komunitas } \mathrm{B}
\end{array} \\
& \text { C }=\text { Koefisien kominitas } \\
& \mathrm{C}>75 \%=\text { Menunjukkan bahwa kesamaan jenis tidak banyak }
\end{aligned}
$$


perbedaan.

$\mathrm{C}<75 \%=$ Menunjukkan bahwa kesamaan jenis banyak perbedaan.

\section{HASIL D A P EMBAHASAN}

Jenis- jenis rumput laut yang tumbuh pada berbagai substrat di pantai Permisan Cilacap, Jawa Tengah berdasarkan hasil identifikasi dari bentuk, ukuran dan warna talus yang dimiliki oleh setiap rumput laut didapatkan 20 jenis. Proposi masing-masing divisi adalah 9 jenis dari divisi Chlorophyta (45\%) meliputi Acrosiphonia coalita, Boegesenia forbesii, Caulerpa taxifolia, Chaetomorpha antenia, Chaetomorpha crassa, Enteromorpha intestinalis, Ulva rigida, Udotea flabellum dan Valoniopsis pachynema, 5 jenis dari divisi Rhodophyta (25\%) meliputi Acanthophora muscoides, Eucheuma serra, Gelidium rigidum, Gracilaria foliifera dan Rhodymenia palmata, dan 6 jenis dari divisi Phaeophyta (30\%) meliputi Dictyopteris sp., Sargassum binderi, Sargassum duplicatum, Sargassum polycytum, Padina australis dan Turbinaria conoides. Jumlah jenis rumput laut di pantai Permisan Cilacap memiliki jenis yang lebih banyak dibandingkan dengan Pantai Karapyak Jawa Barat, hasil penelitian Suryani (2011) di pantai Karapyak didapatkan 11 jenis rumput laut (Tabel 1).

Rumput laut yang tumbuh pada substrat pasir sebanyak 7 jenis yaitu 4 jenis dari divisi Chlorophyta (57,14\%), 1 jenis dari divisi Rhodophyta (14,28\%) dan 2 jenis dari divisi Phaeophyta (28,57\%). Rumput laut yang tumbuh pada substrat karang sebanyak 20 spesies yaitu 9 jenis dari divisi Chlorophyta (45\%), 5 jenis dari divisi Rhodophyta (25\%) dan 6 jenis (30\%). Rumput laut yang tumbuh pada substrat campuran sebanyak 12 jenis yaitu 5 jenis dari divisi Chlorophyta (41,67\%), 5 jenis dari divisi Rhodophyta $(41,67 \%)$ dan 2 jenis dari divisi Phaeophyta (16,66\%) (Tabel 1).

Jumlah jenis rumput laut yang tumbuh pada substrat karang lebih banyak dari pada substrat campuran dan substrat pasir. Substrat karang bersifat stabil sehingga rumput laut dapat melekat kuat pada substrat sehingga tidak mudah terhempas pada saat gelombang besar. Catatan hasil penelitian P20 - LIPI dalam Nybakken (1992) menunjukkan bahwa sebaran habitat rumput laut di Indonesia banyak terdapat pada daerah rataan terumbu karang. Menurut Hartog (1972), bahwa kondisi substrat yang stabil merupakan tempat yang baik bagi pertumbuhan rumput laut. Substrat campuran terdiri atas karang atau pecahan karang yang tercampur pasir sehingga bersifat tidak stabil sehingga mudah terhempas pada saat gelombang besar. Pada substrat pasir jenis yang tumbuh lebih sedikit dibandingkan dengan substrat karang karena pasir merupakan substrat yang mudah terbawa oleh gelombang ataupun arus, selain itu holdfast kurang kuat untuk melekat dan talusnya tidak terlalu kuat. Sahri (2000) menyatakan bahwa substrat pasir mudah sekali terbawa arus air dan menyebabkan distribusi organisme laut menjadi tidak beraturan. Biomassa rumput laut pada ketiga substrat memiliki nilai yang berbeda, nilai biomassa tertinggi pada substrat karang. Tingginya biomassa pada substrat karang dapat dipengaruhi oleh faktor lingkungan, adanya proses dominansi dan morfologi jenis rumput laut yang didapat. Handayani dan Kadi (2007) menyatakan kesuburan dan biomassa rumput laut di suatu perairan tergantung pada faktor lingkungan seperti keadaan substrat, kondisi perairan dan musim.

Biomassa terbesar terdapat pada jenis Ulva rigida dan Valoniopsis pachynema masing-masing rata-rata biomassanya sebesar $2,281 \mathrm{~g}$ dan $0,940 \mathrm{~g}$. Ulva rigida memiliki talus berupa lembaran tipis yang membantu melekat kuat pada substrat sehingga tidak mudah terhempas oleh ombak. Ulva rigida merupakan jenis rumput laut yang paling tahan terhadap paparan cahaya matahari langsung dan dehidrasi sehingga mempunyai nilai biomassa tertinggi. Menurut Nybakken (1992) dan Luning (1990), rumput laut dari marga Caulerpa, Enteromorpha, Ulva, Gelidium dan Glacilaria mempunyai toleransi yang tinggi terhadap dehidrasi atau kehilangan air antara 60-90 $\%$, sehingga masih dapat bertahan hidup meskipun besar talusnya mengering akibat terpapar cahaya matahari langsung.

Jenis rumput laut pada substrat pasir jumlahnya lebih sedikit dibandingkan substrat karang dan campuran karena substrat pasir merupakan substrat tidak stabil. Menurut Chapman (1975) kemampuan melekat rumput laut pada substrat tergantung pada macam holdfast dan kondisi substrat yang ada. Menurut Kuntjoro (1995) keadaan substrat pasir yang tidak stabil menyebabkan jumlah spesies rumput laut yang tumbuh menjadi sedikit.

Hasil perhitungan indeks keanekaragaman rumput laut yang didapat di perairan pantai Permisan Cilacap, Jawa Tengah menunjukkan bahwa ketiga substrat mempunyai komposisi nilai yang berbeda, dengan indeks keanekaragaman berkisar antara 0,0645-0,8289 artinya memiliki indeks keanekaragaman yang rendah (Tabel 2).

Rendahnya tingkat keanekaragaman banyak disebabkan oleh kompleksitas habitat akibat kerusakan substrat atau gelombang tinggi. Faktor lain yang menyebabkan rendahnya keanekaragaman adalah aktivitas manusia yang berlebihan. Atmadja (1999) menyatakan bahwa rumput laut rentan terhadap perubahan atau tekanan ekologis yang mempengaruhinya. Keanekaragaman tertinggi terdapat pada substrat karang diikuti substrat campuran dan terendah pada substrat pasir.

Indeks dominansi berkisar antara antara 0,21321,1932 berarti terdapat jenis yang mendominansi jenis lainnya. Tingginya indeks dominansi menunjukkan adanya persaingan (kompetisi) yang sangat ketat antara anggota komunitas rumput laut tersebut. Menurut Lobban dan Harrison (1994), persaingan antara jenis ada tiga hal yaitu kompetisi dalam memperoleh ruang tumbuh interference compotition, epifitisme, allelopati dan eksploitatif. 
Nilai indeks kemerataan berkisar antara 0,02150,2766 berarti komunitas dalam kondisi labil. Menurut Dahuri (2003) kondisi komunitas yang labil menunjukkan adanya sebaran individu-individu antara jenis tidak merata. Indeks kemerataan yang rendah disebabkan indeks dominansi yang tinggi.
Dominansi yang tinggi menyebabkan persaingan antara jenis rendah. Krebs (2001) menyatakan bahwa semakin kecil nilai kemerataan maka semakin kurang merata distribusi setiap populasi atau semakin tidak merata distribusi jumlah individu tiap jenis atau dominansi oleh suatu jenis tertentu.

Tabel 1. Jenis dan biomassa rumput laut yang tumbuh di pantai Permisan Cilacap, Jawa Tengah

\begin{tabular}{clccc}
\hline \multirow{2}{*}{ No. Jenis Rumput Laut } & \multicolumn{2}{c}{ Nilai Biomassa (gram) } & Jumlah \\
(gram)
\end{tabular}

Tabel 2. Nilai struktur komunitas rumput laut (indeks keanekaragaman, indeks dominansi dan indeks kemerataan) pada berbagai substrat di perairan Pantai Permisan Cilacap.

\begin{tabular}{lcccc}
\hline \multicolumn{1}{c}{ Struktur Komunitas } & $\begin{array}{c}\text { Substrat } \\
\text { Pasir }\end{array}$ & $\begin{array}{c}\text { Substrat } \\
\text { Karang }\end{array}$ & $\begin{array}{c}\text { Substrat } \\
\text { Campuran }\end{array}$ & $\begin{array}{c}\text { Secara } \\
\text { Keseluruhan }\end{array}$ \\
\hline Indeks Keanekaragaman & 0,0645 & 0,8289 & 0,6468 & 1,5402 \\
Indeks Dominansi & 0,9535 & 0,2132 & 1,1932 & 2,3599 \\
Indeks Kemeratan & 0,0215 & 0,2766 & 0,2159 & 0,5140 \\
\hline
\end{tabular}

Tabel 3. Hasil pengukuran parameter pendukung di Pantai Permisan Cilacap, Jawa Tengah.

\begin{tabular}{clccc}
\hline \multirow{2}{*}{ No } & \multirow{2}{*}{ Parameter pendukung } & \multicolumn{3}{c}{ Substrat } \\
\cline { 2 - 4 } & & Pasir & Karang & Campuran \\
\hline 1. & Temperatur $\left({ }^{\circ} \mathrm{C}\right)$ & $29-31$ & $27-30$ & $28-30$ \\
2. & Salinitas $(\%)$ & $34-38$ & $36-40$ & $34-40$ \\
3. & Derajat keasaman $(\mathrm{pH})$ & $7-8$ & $7-9$ & $7-8$ \\
4. & Kedalaman $(\mathrm{cm})$ & $10-15$ & $10-20$ & $15-25$ \\
5. & Kecepatan ombak $(\mathrm{cm} / \mathrm{dtk})$ & $100-150$ & $50-100$ & $50-100$ \\
\hline
\end{tabular}

Suatu komunitas apabila terdapat organisme dengan tingkat dominansi yang tinggi maka keanekaragamannya menjadi rendah. Hal tersebut sesuai dengan pendapat Mackenzie et al., (1998) yang menyatakan bahwa ada hubungan antara keanekaragaman dan dominansi jenis, dimana daerah yang mempunyai tingkat dominansi tinggi akan mempunyai tingkat keanekaragaman yang rendah.

Indeks kesamaan jenis rumput laut tertinggi yaitu pada substrat karang dan campuran 75\% sebanyak 12 jenis, indeks kesamaan pada substrat pasir dan karang $51,8 \%$ sebanyak 7 jenis dan indeks kesamaan terendah diperoleh antara substrat pasir dan campuran 21,05\% sebanyak 2 jenis. Tingginya indeks kesamaan jenis rumput laut pada substrat karang dan campuran disebabkan adanya kemiripan dan komposisi jenis dalam komunitas rumput laut yang lebih besar dibanding dengan substrat lainnya.

Keberadaan rumput laut di perairan Pantai Permisan Cilacap Jawa Tengah dipengaruhi oleh faktor lingkungan yang ada baik fisik maupun kimiawi serta organisme bentik. Data hasil pengukuran faktor lingkungan di Pantai Permisan yang menunjukkan bahwa keadaan faktor fisika dan kimia pada saat 
penelitian dapat dilihat pada Tabel 3 .

Hasil pengukuran temperatur di pantai Permisan pada substrat pasir antara $29-31^{\circ} \mathrm{C}$, pada substrat karang antara $27-30^{\circ} \mathrm{C}$, dan pada substrat campuran antara $28-30^{\circ} \mathrm{C}$. Temperatur di lokasi penelitian masih dalam kisaran normal yang dapat ditoleransi oleh rumput laut. Menurut Aslan (1991) Temperatur optimum untuk pertumbuhan rumput laut berkisar antara $27-30^{\circ} \mathrm{C}$.

Salinitas air laut mempengaruhi penyebaran, kelimpahan dan pertumbuhan rumput laut di suatu perairan pantai. Hasil pengukuran salinitas air laut di pantai Permisan pada substrat pasir antara 34-38\%, pada substrat karang antara $36-40 \%$ dan pada substrat campuran antara 34-40 \%. Kondisi tersebut sangat mendukung pertumbuhan rumput laut sebagaimana pernyataan Bold dan Wyne (1985), bahwa kisaran salinitas optimum untuk pertumbuhan rumput laut antara 33-40\%.

Derajat keasaman atau $\mathrm{pH}$ mempengaruhi pertumbuhan rumput laut. Menurut Anggadireja et al. (2006), kondisi $\mathrm{pH}$ optimum untuk pertumbuhan rumput laut berkisar 6,8-8,2. Derajat keasaman $(\mathrm{pH})$ di pantai Permisan, Cilacap, Jawa Tengah pada substrat pasir adalah 7-8, pada substrat karang 7-9 dan pada substrat campuran 7-8. Hasil pengukuran $\mathrm{pH}$ merupakan kondisi yang cukup ideal untuk pertumbuhan rumput laut.

Berdasarkan penelitian dan pengamatan kedalaman di pantai Permisan pada substrat pasir berkisar antara $10-15 \mathrm{~cm}$ pada saat surut, pada substrat karang berkisar antara $10-20 \mathrm{~cm}$ pada surut surut, dan pada substrat campuran berkisar antara $15-25 \mathrm{~cm}$. Menurut Farid (2008) rumput laut di Indonesia tumbuh baik pada kedalaman $20-30 \mathrm{~cm}$ tersebut, karena umumnya penetrasi cahaya matahari masih baik dan mencapai kedalaman tersebut. Perairan yang terlalu dangkal akan menghambat pertumbuhan rumput laut, karena selain dasar perairan mudah teraduk sehingga menimbulkan kekeruhan yang mengganggu proses fotosintesis, tanaman juga akan mudah dicapai oleh predator seperti penyu maupun bulu babi.

Menurut Serdiati dan Widiastuti, (2010) pergerakan air yang diakibatkan gelombang permukaan sangat membantu dalam distribusi unsur hara dan fisika kimia air lainnya baik secara horisontal maupun vertikal dalam suatu wilayah perairan. Arus yang baik untuk pertumbuhan rumput laut antara 20-40 cm/detik. Pengukuran kecepatan arus/ombak pada substrat pasir $100-150 \mathrm{~cm} /$ detik, pada substrat karang $50-100 \mathrm{~cm} /$ detik dan pada substrat campuran 50-100 cm/detik. Berdasarkan kisaran tersebut kecepatan arus pada lokasi penelitian melebihi syarat yang baik untuk pertumbuhan rumput laut. Anggadireja et al. (2006) menyatakan bahwa apabila gelombang maupun ombak dengan tekanan yang relatif kuat maka menyebabkan talus rumput laut rusak, namun beberapa jenis rumput laut mampu bertahan pada saat gelombang yang besar.

Perkembangan rumput laut tidak lepas dari pengaruh luar, misalnya kompetisi antar jenis rumput laut, pemangsaan oleh hewan laut misalnya keberadaan bulu babi, teripang, bintang laut dan hewan herbivora yang dapat merusak talus rumput laut dengan memakannya sehingga akan mengurangi jumlah spora dan menghambat penyebaran rumput laut (Luning,1990).

\section{KES I M P U LA N DAN SARA N}

Berdasarkan hasil penelitian dan pembahasan maka dapat diambil kesimpulan sebagai berikut:

1. Jenis rumput laut yang terdapat di pantai Permisan sebanyak 20 jenis dengan total biomassa sebesar 4,669 g. Rumput laut yang paling banyak ditemukan pada substrat karang sebanyak 20 jenis dengan biomassa sebesar 2,399 g, substrat campuran sebanyak 12 jenis dengan biomassa sebesar 1,634 g dan substrat pasir sebanyak 7 jenis dengan biomassa sebesar 0,636 g.

2. Pantai Permisan memiliki keanekaragaman jenis rumput laut rendah yang didominansi oleh Ulva rigida, pertumbuhan dan penyebaran rumput laut tidak merata antar substrat. Pantai Permisan memiliki kesamaan jenis rumput yang tinggi terdapat pada substrat karang dan campuran sebesar 75\%.

Pantai Permisan merupakan pantai dengan keanekaragaman jenis yang rendah dan pertumbuhan rumput laut yang tidak merata, oleh karena itu perlu adanya usaha pelestarian rumput laut, diantaranya dengan cara budidaya yang ramah lingkungan tanpa mengganggu komunitas rumput laut alami untuk perlindungan dan pengendalian lebih lanjut terhadap pelestarian rumput laut.

\section{A F T AR REFERE N S I}

Alaerts G, Santika SS. 1987. Metode Penelitian Air. Surabaya: Usaha Nasional.

Anggadiredja JT, Zatnika A, Purwoto H, Istini S. 2006. Rumput Laut. Jakarta: Penebar Swadaya.

Aslan LM. 1991. Budidaya Rumput Laut. Yogyakarta: Kanisius.

Bold HC, Wynne MJ. 1985. Introduction to the Algae. 2nd ed. New Jersey: Prentice-Hall, Inc.

Chapman CJ. 1975. Coastal Vegetation. Oxford: Pergamon Press.

Dahuri R. 2003. Keanekaragaman Hayati Laut: Aset Pembangunan Berkelanjutan Indonesia. Jakarta: Gramedia Pustaka Utama.

Fachrul MF. 2007. Metode Sampling Bioekologi . Jakarta: Bumi Aksara.

Farid A. 2008. Studi Lingkungan Untuk Budidaya Rumput Laut (Eucheuma cottonii) Di Perairan Branta, Pamekasan, Madura. Jurnal Penelitian Perikanan. 11: 1- 6.

Handayani T, Kadi A. 2007. Keanekaragaman dan Biomassa Algae di Perairan Minahasa Utara, Sulawesi Utara. Jurnal Oseanologi dan Limnologi di Indonesia. 33(2): 199-211.

Hartog D. 1972. Substratum Plant-Multicelluler Plant. Environmental Factor. London: Willey Interscience. 1277-1366 p.

Indrawati G, Arthana IW, Merit IN. 2007. Studi Komunitas Rumput Laut Di Pantai Sanur Dan Pantai Sawangan Nusa Dua Bali. Ecotrophic. 4 (2) : 73 - 79

Indrawati G, Atmadja WS. 1988. Rumput Laut (Algae): Jenis Reproduksi, Budidaya dan Pasca Panen. Jakarta: Pusat Penelitian dan Pengembangan Oseanologi LIPI. 
Krebs CJ. 2001. Ecology. The Experiment Analisys of Distribution and Abundance $5^{\text {th }}$ First Edition. New York: Harper and Row, Publishers.

Kuntjoro EB. 1995. Studi Perbandingan Kepadatan dan Sebaran Rumput Laut di Pantai Pacitan Jawa Timur dengan Pantai Sadeng Yogyakarta [skripsi]. Universitas Jenderal SoedirmanPurwokerto.

Kuntjoro EB, Horrison PJ. 1994. Seaweed: Ecology and Physiology. UK: Cambridge University Press.

Luning K. 1990. Seaweeds Their Environment, Biogeograph and Ecophysiology. New York: John Wiley \& Inc.

Mackenzie A, Ball AS, Virdee SR. 1998. Instant Notes in Ecology. Singapore: Bios. Scientific Publisher.

Nybakken J W. 1992. Biologi Laut Suatu Pendekatan ekologis [diterjemahkan oleh HM Eidman]. Jakarta: Gramedia Pustaka Utama.

Odum EP. 1971. Fundamental of Ecology. 3rd ed. London: Toppan Company, Ltd.

Sahri A. 2000. Keanekaragaman Makrobentos pada Berbagai Substrat Buatan di Sungai Ciglagah Cilacap. Biosfera. 15: 8531625.

Serdiati N, Widiastuti IM. 2010. Pertumbuhan dan Produksi Rumput Laut Eucheuma cottonii pada Kedalaman Penanaman Yang Berbeda. Media Litbang Sulteng. III (1): 21 - 26.

Suryani FM. 2011. Keanekaragaman dan Dominansi Rumput Laut Hidrokoloid Pada Substrat Dasar Berbeda di Pantai Karapyak Jawa Barat [skripsi]. Universitas Jenderal SoedirmanPurwokerto. 